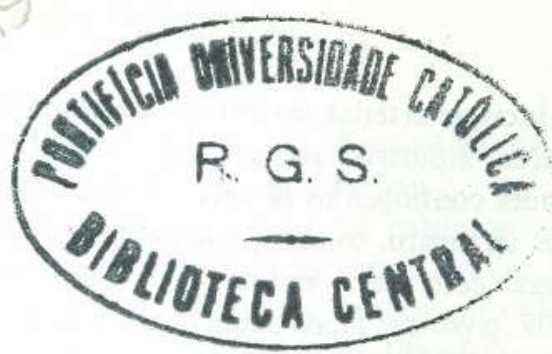

\title{
QUESTÃO DE HONRA: A GREVE DOS FERROVIÁRIOS DA COMPANHIA PAULISTA, 1906
}

Tania Regina de Luca*

A construção das ferrovias paulistas subor dinou-se, em larga medida, aos interesses do café. A elas coube o importante papel de tornar viável a ocupação - pela agricultura de exportação - das terras férteis do interior do Estado. A primeira "ferrovia do café" foi a São Paulo Railway Company, empresa inglesa inaugura da em 1867 que ligava Santos a Jundiaí. Toda produção cafeeira paulista passava obrigatoriamente pelos seus trilhos em busca do porto de embarque. A desistência da companhia inglesa do seu direito de preferência para coṇstruir o prolongamento da linha abriu oportunidade para a participação do capital nacional. ${ }^{1}$ Assim, em 1868, os cafeicultores constituiram a Companhia Paulista de Estradas de Ferro, com o propósito de ligar Jundiaí a Rio Claro. O primeiro trecho, até Campinas, começou a operar em 1872, sendo que quatro anos depois a Paulista alcançava Limeira e Rio Claro.

O empreendimento mostrou-se desde logo muito lucrativo. Os dividendos pagos anualmente aos acionistas foram, em média, superiores a $10 \%{ }^{2}$ Visando obter o quase monopólio dos transportes numa das áreas mais populosa e dinâmica do Estado, a Paulista adquiriu em 1892 a Companhia Rio Claro que estendia-se desta cidade até Araraquara, passando por São Carlos, Brotas, Dois Córregos e Jaú, todos municípios tributários do café. ${ }^{3}$ Em 1900 a Companhia Paulista possuía $863 \mathrm{~km}$ de trilhos, o que representava um quarto do total do Estado, que então contava com $3468 \mathrm{~km} .{ }^{4}$ A dependência da empresa em relação a empréstimos externos foi pequena. Somente por três vezes eles foram solicitados: em 1878; em 1892, quando da compra da Companhia Rio Claro; e em 1922, para eletrificação de parte da linha; todos honrados dentro do prazo. ${ }^{5}$

As ferrovias, além de serem fundamentais para o bom desempenho da agro-exportação, representavam uma oportunidade lucrativa de aplicação do capital gerado pelo café. Elas ocupavam posição de destaque no conjunto da economia do período. Basta citar que a receita conjunta da Paulista e 
da Mogiana, principais artérias do Estado, equivalia no ano de 1907 a $71 \%$ de toda produção industrial paulista e a $95 \%$ da têxtil. ${ }^{6}$ Essas empresas absorviam grandes contingentes de mão-de-obra, tanto no tráfego como na rede de oficinas de reparo, construção e montagem. No final do século XIX, a Paulista figurava com maior empregadora industrial do Estado. ${ }^{7}$ Segundo o censo de 1907 , o parque fabril paulista ocupava 24.186 pessoas, enquanto que as ferrovias, em 1910, tinham 18.501 emprega dos. $^{8}$

Entretanto, a Paulista era mais do que uma estrada de ferro lucrativa situada numa posição estratégica, ela era um símbolo da capacidade empreendedora dos produtores de café, bem como de seus múltiplos interesses:

\begin{abstract}
"The Paulista's founders were leaders whose business, political and family affairs bridged urban and rural domains. These urban agriculturalists organized themselves and raised the capital necessary to form the Companhia Paulista and lay its first strecht of track between Jundiaí and Campinas. Their example provide a rare oportunity to view a landed elite combining the necessary elements to produce and industrial innovation of the railroad's magnitu de". 9
\end{abstract}

Saldanha Marinho, presidente da Província, referiu-se à fundação da Companhia em termos en tusiásticos:

" $\hat{E}$ o primeiro exemplo desta ordem no país. $\hat{E}$ a primeira companhia brasileira que, em ponto tão elevado, abstrai de capitais estranhos e se liberta do jugo estrangeiro. $\hat{E}$ um fato de alcance enorme para o futuro". 10

A Paulista ligou-se, desde o início, à familia Prado. Apesar de não figurarem como importantes acionistas da companhia, os Prado foram seus promotores, administradores e financiadores. Martinho Prado, além de organizador, foi um importante captador de fundos e um dos seus primeiros diretores. Eduardo Prado negociou a compra da Rio Claro e na diretoria sempre figuraram membros da família. Contudo, foi Antônio Prado quem ocupou a posição de maior destaque, tendo sido seu presidente por trinta e seis anos, de 1892 a $1929 .{ }^{11}$ Durante a Primeira República, Antônio foi o representante mais ilustre da familia. Ocupou todos os cargos do Poder Legislativo Estadual e Federal, chegando a senador em 1867. Foi ministro do Império por mais de uma vez, Conselheiro do Imperador, Prefeito de São Paulo de 1899 a 1910. Pioneiro na exploração das terras do oeste, defendeu a escravidão até o momento em que a solução imigrantista se tornasse um fato concreto ${ }^{12}$ Além da produção e comercialização do café, essa feita pela casa Prado-Chaves, ocupou-se da fundação de in dústrias de vidro, couro e alimen- 
to. Dono de enorme fortuna pessoal, atingiu prestígio incomparável ao de qualquer outro membro da elite dominante do país.

A Paulista era encarada como parte do patrimônio da família e enquanto tal deveria adequar-se aos interesses mais amplos dos Prado. Nessa medida, é sintomática a atitude tomada por Antônio quando a Mogiana atingiu seus domínios pessoais na Santa Veridiana. Ele preferiu construir um ramal da Paulista até sua fazenda do que embarcar a produção numa "ferrovia rival", e isso antes mesmo de assumir a presidência da companhia. ${ }^{13}$ Sua longa administração foi considerada exemplar. A empresa estendeu suas linhas, eletrificou parte delas e introduziu carros de aço e locomotivas modernas. ${ }^{14}$ Entre 1905 e 1906 foram incorporadas novidades tecnológicas poupadoras de mão-de-obra.

Essa política de atualização técnica, aliada aos baixos salários e prolongadas jornadas, foi responsável pela greve que estancou completamente o tráfego de 15 a 31 de maio de 1906. Na da menos que 3500 dentre os 3800 funcionários da companhia abandonaram o trabalho. Desde o início, o movimento dispertou ampla simpatia popular. Operários, estudantes, comerciantes e até fazendeiros manifestaram-se a favor dos grevistas. $\mathrm{O}$ movimento espalhou-se por toda a linha e atingiu São Paulo, que viveu a sua primeira greve geral, decretada em solidariedade aos emprega dos da Paulista. O desenrolar dos fatos evidencia que nesse momento as relações entre o capital e o trabalho ainda apareciam fortemente marcadas pela visão patriarcal. Os conflitos, quer por parte dos. operários, quer pelos patrões, acabaram por se individualizar e personificar, quando na verdade era a forma de exploração capitalista que estava em jogo.

\section{I) 1906: A CONJUNTURA POLÍTICA}

A eclosão da greve de 1906 na Companhia Paulista, bem como as repercusões que a mesma alcançou, pode ser melhor compreendida se inserida na ampla investida levada a cabo, durante o primeiro semestre daquele ano, pela liderança operária no sentido de mobilizar a classe. ${ }^{15}$ Certamente entre os principais acontecimentos do período está a realização no mês de abril do Primeiro Congresso Operário Brasileiro, no Rio de Janeiro, cuja finalidade era traçar normas para a ação e organização do conjunto da classe. ${ }^{16} \mathrm{~A}$ análise das resoluções aprovadas na oportunidade torna patente que os anarquistas conseguiram impor suas idéias sobre as demais correntes do movimento. ${ }^{17} \mathrm{~A}$ primeira manifestação significativa após o Congresso foi a comemoração do dia do trabalho, que conseguiu reunir grande quantidade de traba- 
lhadores em vários comícios e conferências realizadas em São Paulo, Rio de Janeiro e Campinas, nas quais exigia-se as oito horas de trabalho e condenavam-se as violências cometidas pelo czar contra os revolucionários russos. ${ }^{18}$ Everardo Dias atribuiu particular importância às manifestações do primeiro de maio de 1906, afirman do que naquele ano abandonou-se a tendência de comemorá-lo com "bailes, piqueniques, passeatas com banda de música, foguetórios, alvorada com disparos de morteiros e rojões e outras bambochatas espetaculosas que disvirtuavam completamente a finalidade da data". ${ }^{19}$ Tal mudança de enfoque é explicada pelo autor como reflexo da adoção das determinações do Primeiro Congresso Operário Brasileiro. De fato, este, na sua segunda resolução, afirmava:

\begin{abstract}
"O Primeiro Congresso Operário Brasileiro verbera e reprova in dignamente as palhaçadas feitas no primeiro de maio com o concurso e complacência dos senhores; incita o operaria do a restituir ao primeiro de maio o caráter que lhe compete; de sereno, mas desassombrado, protesto e de enérgica reivindicação de direitos ofendidos ou ignorados". 20
\end{abstract}

Nessa onda de mobilização, os ferroviários receberam particular dose de atenção. No mês de março foram fundadas, com a participação de elementos libertários, as Ligas Operárias de Jundiaí (11/03/1906) e de Rio Claro $(25 / 02 / 1906)$ que, juntamente com a também recém-criada Liga Operária de Campinas (17/12/1905), congregavam significativo número de trabalhadores da Paulista. ${ }^{21}$ Essas agremiações tinham caráter combativo e visavam obter melhores condições de vida e trabalho, incluindo-se aí a jornada de oito horas. ${ }^{22}$ Igualmente digno de destaque é o fato de militantes da envergadura de Edgard Leuenroth e Everardo Dias terem discursado no primeiro de maio em Campinas e Jundiaí. Nesta última cidade, compareceram ao comício da Liga perto de 5000 pessoas que ouviram uma exposição de Leuenroth sobre o Primeiro Congresso Operário Brasileiro, do qual participara ativamente, além de João Correia e Manuel Pisani, que tiveram papel destacado na greve que se iniciaria poucos dias depois. ${ }^{23}$

É surpreendente que, apenas dois meses após a criação das Ligas, elas conseguissem representar a quase totalidade dos operários da Companhia Paulista, bem como liderar uma greve - violentamente reprimida desde o início - por quinze dias. Não se pode esquecer que os trabalhadores estavam espalhados ao longo das várias cidades servidas pela Companhia, o que apesar de ser um fator natural de dispersão, não impe diu que as ligas conseguissem a adesão de todas as estações. Para além dos esforços desenvolvidos pela cúpula do movimento, essa aceitação demonstra o profundo descontentamento existente nos meios ferroviários. 


\section{II) O MOVIMENTO GREVISTA: CAUSAS E REIVINDICAÇÕES}

O estopim para o início da greve na Paulista foi a transferência de um emprega do de Jundiaí para Ribeirão Bonito. Este, sentindo-se lesado, recorreu à Liga Operária de Jundiaí que intercedeu a seu favor junto ao Inspetor Geral por meio de dois ofícios, datados de 28/04 e 02/05/1906, nos quais eram pedidas providências em relação ao chefe da estação de Jundiaí, acusa do não só de perseguir o funcionário transferido, como também de "múltiplas arbitrariedades, opressões e abusos... em prejuízo do pessoal". ${ }^{24}$ Apesar do tom de ameaça, as críticas não eram extensivas à empresa, cuja figura era preservada:

\footnotetext{
"Visto a atitude exalta da e geral indignação do pessoal da Companhia acerca das contínuas ameaças e insultos que o chefe da estação... dirige aos seus subalternos e mais pessoal da Companhia... somos forçados a pedir a V.S. dar-nos uma solução até sábado, não podendo esta digna corporação de honestos operários ser alvo das infâmias deste baixo chefe, que é indigno até de ser emprega do de uma importante ferrovia como a Companhia Paulista", 25
}

Mediante o não atendimento desses apelos, os operários abandonaram o serviço no dia $15 / 05$.

Certamente o início do movimento grevista não foi uma surpresa para a direção da empresa. Antônio Prado, presidente da Paulista, ao ser informado dos acontecimentos, declarou que lhe haviam chegado "rumores de uma parede". ${ }^{26}$ Torres Neves, inspetor geral, admitiu ter sido procurado por uma comissão do pessoal da estrada que reivindicava os mesmos itens que eram objeto da greve. Alguns jornais do interior chegaram mesmo a noticiar o fato com antecedência, permanecendo em aberto apenas o dia em que o movimento rebentaria. ${ }^{27}$ Tudo isso indica que a greve foi cuidadosamente prepara da e que contava com a aprovação da maioria dos empregados. Segundo boletim da Liga de Jundiaí, amplamente distribuído no primeiro dia de paralisação, as reivindicações dos operários eram: a demissão do engenheiro Francisco Paes Leme de Manlevade do seu cargo de chefe da locomoção, do seu ajudante Henrique Burnier e de chefe da estação de Jundiaí, João Gonçalves Dias; além da não obrigatoriedade de inscrever-se na Sociedade Beneficente patrocinada pela Companhia. ${ }^{28}$

Nas primeiras décadas desse século, as relações entre operários e superiores imediatos foram objeto de várias greves. A inexistência de qualquer mediação institucional entre o capital e o trabalho tornava ainda mais pesada a exploração econômica e moral do operaria do. Assim, não poucas vezés, 
a arbitrarie dade dos chefes, as violências cometidas contra crianças e mulheres explodiam sob a forma de violentos conflitos. Vale lembrar que os patrões conduziam suas empresas como bem thes aprouvesse: determinavam a duração da jornada, o ritmo de produção, o montante dos salários, bem como a forma de pagá-los; além de criarem regulamentos internos que quando desobedecidos importavam em multas. ${ }^{29}$ Pelas causas mais insignificantes o indivíduo era dispensado, pois, graças à abundância de mão-de-obra, não havia problemas em encontrar substitutos dispostos a venderem-se ao capital, ain da que por míseros salários. A ausência dos mais elementares direitos previdenciários, as longas permanências em ambientes insalubres, os baixos salários, o despotismo patronal e o temor de perder o emprego faziam com que a insegurança fosse o único elemento perene na vida do trabalhador.

Contudo, no caso do movimento da Paulista, a revolta contra os superiores, que se concentrou na pessoa do chefe da locomoção, não pode ser circunscrita aos elementos apontados, ela tem raízes muito mais profundas que precisam ser evidenciadas.

A. diretoria da Paulista, "com o fim de melhorar o serviço da Companhia", ${ }^{30}$ incumbiu o engenheiro Monlevade de fazer uma viagem aos Estados Unidos a fim de estudar as novidades existentes no serviço de locomoção. Ao retornar, ele introduziu nas máquinas aperfeiçoamentos que implicaram

“...além de grande proveito, apreciável economia, motivo porque reduziu de cento e tantos os empregados da tração e do tráfego, aos quais, entretanto, a Paulista adianta de um a dois meses de ordenado como auxílio". ${ }^{31}$

Segundo Antônio Prado, a redução do quadro de empregados foi atenuada pela opção de dispensas do trabalho às segundas-feiras,

“...tornando-se possível a permanência de alguns operários sem alteração nos orçamentos da companhia, međida que encontrou aprovação no seio dos operários". ${ }^{32}$

No primeiro dia de paralisação, o conselho administrativo da Liga Operária de Jundiaí enviou uma longa carta ao Inspetor Geral expondo detalhadamente os motivos do descontentamento reinante entre os operários. Tanto nesse documento, quanto nos vários boletins distribuídos ao longo da greve, fica evidente que a crescente tecnificação introduzida pela Companhia, com todas as conseqüências daí advindas, havia sido apreendidas de maneira personificada. $\mathrm{O}$ responsável pela locomoção era tomado como fon- 
te de todos os males. Constantemente os operários comparavam a situação em que se encontravam com o "tempo do Sr. Silveira", chefe anterior. Escapava-lhes completamente a problemática central, representada pela introdução de nova tecnologia poupadora de mão-de-obra. ${ }^{33}$

\begin{abstract}
"Não é de hoje que o operariado e demais empregados da tração e do tráfego estão sofrendo as perseguiçōes do Sr. Monlevade. Não satisfeito em fazer comemorar qualquer dia santificado ou feriado, mandou fazer feriado três segundas-feiras por mês, exigindo do pessoal o mesmo serviço e ainda mais de quando trabalhava-se seis dias por semana. Esta imposição, que reduziu o nosso ordenado de mais de $10 \%$, não era suficiente para satisfazer as exigências do Sr. Monlevade, que ainda lançou na miséria, dispensando-os do serviço, centenas de chefes de família, pretendendo ainda mais reduzir o pessoal de certas repartiçōes de $30 \%{ }^{34}$
\end{abstract}

Concomitantemente, exigia-se dos operários maior produtividade, sem que isso importasse em aumento nos vencimentos:

\begin{abstract}
"Naquele tempo [do chefe anterior] cada limpador tinha uma máquina para limpar por noite, os ordenados variavam de $3 \$ 500$ e $4 \$ 500$, não faziam serviços estranhos à sua categoria... E o que acontece hoje? Em Porto Ferreira há quatro máquinas e dois limpadores, em Cor deiros quatro máquinas e três limpadores... E quanto ganham hoje? $70 \$ 000$ e $100 \$ 000$ mensais. Além de tudo quando alguém comete a grande falta de pedir pelos seus direitos é maltratado com palavras ou ameaça do com multa ou demissão. Há limpadores que trabalham cinco e seis anos e ganham apenas $3 \$ 500$ por dia. Na repartição dos batidores de roda, a turma era composta de seis ou sete homens, sendo que o encarregado ganhava de $230 \$ 000$ para cima, o ajudante 160 a $180 \$ 000$. Atualmente o serviço é feito por quatro homens sendo o ordenado máximo de $160 \$ 000$. O serviço é o duplo do que era antigamente". ${ }^{35}$
\end{abstract}

Entretanto, o que mais parecia desgostar os trabalhadores era a quebra da antiga hierarquia profissional. $\mathrm{O}$ desrespeito às funções tradicionalmente atribuídas à cada cargo e à evolução limpador - foguista - maquinista era tomada como um "desprestígio aos subor dinados", exatamente por borrar posições "conquistadas" pelo esforço e capacidade individual. Aqueles que não passassem pelos vários estágios eram tido como "estranhos à classe":

"Não sendo nunca rebaixados naquele tempo [do chefe anterior] de maquinista para foguista e de foguista para limpadores, e os limpar dores dispensados, o que acontece hoje a título de economia. Por 
isso o dr. Francisco de Monlevade só tem desprestigiado os seus subordinados, pois que, em tempo de safra, em vez de nomear foguistas para maquinistas... faz ocupar esses lugares por emprega dos de outras categorias, os quais percebem or denados de $400 \$ 000$ e mais. E atualmente ainda existe um em Porto Ferreira que é estranho à classe, e para ele estar ocupando o lugar que não ganhou, estão ocupando maquinistas e foguistas em descarga de lenha e carvão, carregando lixo, construindo pontes e outros serviços em que em outros tempos nunca foram ocupados, o que não acontece em outras Companhias". 36

Vale ressaltar, ainda uma vez, que a Companhia nunca foi atacada diretamente. Pelo contrário, a argumentação caminha no sentido de identificar os reais interesses da Paulista com os de seus operários. Nessa medida, os altos funcionários são apontados como dispensáveis por receberem salários elevados sem colaborarem para o "bem" da Paulista, além de usufruirem ilicitamente da mesma. Já os operários, ver dadeiros carros - chefe da empresa, toleravam toda sorte de abusos, sem receberem o devido reconhecimento:

“...é preciso pagar fabulosos ordenados aos srs. Henrique Burninier, Gabriel Penteado, Maciel, os quais não concorrem com nenhum benefício a bem da Companhia e não são mais do que algozes a mando do Sr. Dr. Monlevade (...). Para que são precisos em Campinas dois chefes de depósito fazendo o mesmo serviço com grave prejuízo da Companhia, pois que, além de utilizarem-se da lenha (é verdade), ainda ocupam dois empregados para levar a lenha a casa todos os sábados. Se esses empregados acima descritos fossem dispensados do serviço da Companhia, esses ordenados fabulosos e desnecessários já podem ser divididos pelos operários que tudo fazem e pouco ganham". 37

Nas passagens citadas transparece nitidamente que os operários esperavam cumprir uma "carreira operária" e que eles identificavam-se com as funções exercidas. Esse relacionamento não meramente econômico com o trabalho, característico da produção artesanal, se apresenta com todo vigor na declaração do líder Manuel Pisani:

“...nós não pedimos aumento de salário, nem redução de horas: o que queremos é um superior digno, correto, humanitário, que compreenda que o operário não é uma máquina inconsciente, mas um homem que trabalha com consciência e tem necessidade não só do vil metal em pagamento do seu trabalho, mas também da satisfação moral que lhe dá direito sua cultura". ${ }^{38}$ 
Resta a impressão de que os operários eram movidos pelo orgulho que tinham do seu of ício e pela certeza de que agiam consoantes com a ética do trabalho. Essa maneira de conduzir a questão denuncia a origem dessa força de trabalho: imigrantes egressos de um meio on de a tradição artesanal remontava a séculos. Sobretudo é interessante marcar que esse apego a padrões pré-capitalistas manifestou-se num setor de produção eminentemente moderno como eram as ferrovias. Por outro lado, não se pode esquecer que o próprio anarquismo veiculava uma moral cuja pedra de toque era a valorização do trabalho e da profissão. $O$ fato é que a dominação capitalista, nesse primeiro momento da luta entre o capital e o trabalho, foi apreendida como se fosse o resultado da atuação de indivíduos tidos como "inimigos dos trabalhadores".

Além da dispensa de alguns funcionários superiores, os grevistas reivindicavam a não obrigatoriedade de pertencer à Sociedade Beneficente. Segundo os estatutos publicados no Diário Oficial do Estado de São Paulo, em 03/05/1906, esta sociedade foi fundada em 1895, sendo seus fins: prestar socorros médicos e farmacêuticos aos sócios e seus familiares, dar pensão àqueles que por moléstias, velhice ou doença tornassem-se incapazes para o exercício de seu cargo, auxiliar no funeral dos sócios e fornecer uma contribuição mensal à familia dos membros falecidos. A receita dessa agremiação provinha das mensalidades pagas por cada empregado e de uma importância dada anualmente pela companhia a título de subvenção. ${ }^{39}$

Em realidade, esse tipo de organização estava bastante difundido nas primeiras décadas do século. Não só se criavam sociedades beneficentes entre os funcionários de uma mesma empresa, como também era muito comum a existência de mutuais entre os imigrantes, normalmente agrupando indivíduos de um mesmo país ou região, entre operários que exerciam profissões similares, ou entre os habitantes de um mesmo bairro. ${ }^{40} \mathrm{Sem}$ dúvida, tais sociedades, em boa parte fundadas pelos próprios interessados, devem ser encaradas como uma resposta à constante insegurança em que vivia o trabalhador. Elas eram, no mais das vezes, sustentadas pelos seus membros, que abriam mão de parte de seus ganhos para assegurarem-se contra as incertezas futuras. Nessa medida, quando o indivíduo estivesse impedido de participar ativamente do processo produtivo poderia contar com um seguro que ele próprio havia se incumbido de pagar.

A exemplo da Paulista, várias empresas, sobretudo no setor terciário, organizaram sociedades beneficentes. Todavia, não se deve detetar nessa atitude finalidades altruísticas do patronato. As mutuais implicavam em considerável redução compulsória nos já parcos salários dos operários, sendo que poucas vezes os trabalhadores encontravam alguma contrapartida prática em tal filiação. Parece ser esse o caso da Sociedade Beneficente dà Companhia Paulista: 
“...o sório doente não pode contar nem com a receita, nem com as drogas, porque o médico e o farmacêutico os recebem mal e servem pior de modo que são obriga dos a recorrer a outros". ${ }^{41}$

Por outro lado, não se pode descartar a hipótese de que a fundação dessas entidades, através da iniciativa patronal, visasse dificultar a constituição de organizações controladas pelos próprios operários. Vale lembrar que o artigo dez dos estatutos da sociedade estabelecia que

"A Sociedade será administra da por uma diretoria composta de cinco membros que serão os sócios que exercerem os cargos de inspetor geral, de chefe de serviço, de contador ou de almoxarife da Companhia Paulista de Vias Férreas e Fluviais, servindo de presidente o inspetor geral". 42

Obviamente, o controle da sociedade escapava completamente aos interessados.

Pelo exposto, fica evidente que na prática as mutuais patrocinadas pelo capital representavam tanto um meio de estorquir parte dos salários, quanto um instrumento de controle. Esses aspectos não escaparam à liderança anarquista, que sempre combateu tais agremiações por considerarem que

“...elas existem para a manutenção de alguns privilegiados e inconscientes trabalhadores, e para subsidiarem aqueles que as dirigem". 43

$\mathrm{Na}$ imprensa do período pode-se encontrar verdadeiras campanhas contra a fundação de socie dades beneficentes. ${ }^{44}$

No caso da Paulista, em nenhum momento a Liga Operária de Jundiaí, porta-voz dos grevistas, encetou uma análise mais circunstanciada a respeito dos reais objetivos que, muito provavelmente, envolviam a fundação da sociedade beneficente. Assim, os senões apresentados pelos ferroviários contra a sociedade foram novamente associados à atuação do engenheiro Monlevade:

"A fim de ocupar alguns parentes e protegidos, decretou obrigatória para os empregados da Companhia Paulista a sociedade beneficente, devendo portanto cada empregado pagar $3 \$ 000$ mensais a dita sociedade que são descontados no pagamento e cujo rendimento é totalmente absorvido em ordenados fabulosos de médicos inábeis e desumanos que pouco se importando com os enfermos transcuram-nos ou negam-se a visitá-los, receitando medicamentos que nada fazem e que mais prejudicam do que favorecem a cura". 45 
Tendo em vista os aspectos destacados, não deve causar admiração o fato da demissão do engenheiro Monlevade ter se tornado o ponto fulcral das reivin dicaçõos operárias.

\section{III) A DINÂMICA DO MOVIMENTO}

Imediatamente após ter sido deflagrada a greve, a diretoria da Paulista afirmou categoricamente que, apesar de estar disposta a entrar em acordo com os grevistas, não tomaria nenhuma atitude que implicasse no desprestígio de funcionários superiores. ${ }^{46} \mathrm{Em}$ relação à sociedade beneficente, já no dia seguinte ao início do movimento, foi anunciada pelos jornais a convocação de uma assembléia geral com o propósito de reformular o artigo dez dos estatutos que dispunha sobre a administração da sociedade. ${ }^{47}$ Contudo, a impossibilidade de uma solução conciliatória ficou patente quando as queixas apresenta das por uma comissão de grevistas contra o engenheiro Monlevade não foram aceitas por Antônio Prado, que inclusive recusou o pedido de demissão feito pelo mesmo, alegando que "estava certo de que passada a agitação de ânimo que atualmente domina o espírito dos operários, que atribuía a influências estranhas, (...) reconheceriam a injustiça que fazem ao superior". ${ }^{48}$ Os grevistas, por sua vez, declararam-se firmes no propósito de não voltarem ao trabalho antes da dispensa do chefe da locomoção.

Esse tipo de confrontamento direto entre patrões e operários foi característico das primeiras décadas do século. O Estado, por adotar certas posturas do liberalismo clássico, insistia em relegar as relações capital-trabatho ao direito privado, como se elas disessem respeito unicamente às partes envolvidas. Obviamente este posicionamento vinha ao encontro dos interesses patronais, já que possibilitava aos industriais aumentarem sua taxa de lucro através da super exploração do trabalho sob um regime onde os rigores do cativeiro ain da ecoavam. ${ }^{49}$

Não se pense, contudo, que a liderança bradasse pela intervenção estatal. A "ação direta", tática fundamental do anarquismo, baseava-se justamente na crença de que os próprios trabalhadores deveriam lutar pelos seus direitos, sem a mediação de nenhuma instituição. Todavia, os resultados práticos obtidos na luta contra o capital foram minguados. Reivindicações penosamente alcançadas através de inúmeras greves eram pouco depois subtraídas pelo arbítrio patronal. $\mathrm{O}$ direito de greve, apesar de reconhecido pelo Código Civil, nunca foi respeitado e os operários sempre tiveram que suportar violentas interven ções da política, fiel aliada dos empresários.

Nesse sentido, o movimento de 1906 na Paulista caracterizou-se pela intervenção particularmente exarcebada do aparelho repressivo estatal. Sem 
dúvida, concorreu para isso o fato da Companhia ser uma artéria fundamental para o escoamento da produção de café, ocupando assim posição estratégica no conjunto da economia. Por outro lado, é importante marcar que a figura do seu presidente, o Conselheiro Antônio Prado, na época Prefeito de São Paulo, desfrutava de grande projeção no cenário político nacional, o que lhe possibilitou encontrar acolhida inconteste tanto do governo estadual quanto do federal. Possivelmente, o que mais atemorizou as classes dominantes foi a percepção de que não se encontravam diante de uma simples explosão de cólera provocada por insuportável exploração, mas que enfrentavam, pela primeira vez, um movimento que estava longe do espontaneísmo e que suscitou manifestações de solidariedade por parte de diversos segmentos sociais. ${ }^{50}$

As atitudes da Companhia durante a greve revelam que ela optou pela imediata repressão: já no primeiro dia de paralisação, os operários foram convocados a reassumirem seus postos sob pena de demissão. ${ }^{51}$ Pouco depois, a Paulista procurava restabelecer pelo menos uma parte do tráfego, utilizando-se do seu pessoal superior; contratando maquinistas e foguistas para substituir os grevistas; recebendo auxilio da Light, que lhe enviara diversos motorneiros e condutores; bem como da armada, que colocou seus oficiais à disposição. ${ }^{52}$

Entretanto, todos esses esforços revelaram-se inúteis, pois os grevistas preparam inúmeras armadilhas, visando obstar o andamento dos comboios: esvaziavam as caixas d'água ao longo de toda a linha e cortavam os canos e bombas que as abasteciam; colocavam sabão nos trilhos e nas caldeiras, cortavam os fios telegráficos e afrouxavam as chaves de estrada. ${ }^{53}$ De fato, um trem dirigido pelos altos funcionários da empresa levou mais de dez horas para ir de Jundiaí a Campinas. A intervenção da polícia não se fez esperar. Praças da força pública foram espalhados ao longo de toda a linha, os poucos trens que circulavam passaram a contar com forte esquema de vigilância e as cidades de Campinas e Jundiaí eram patrulhadas ostensivamente dia e noite, a ponto de darem a impressão de que "se achavam sob estado de sítio". ${ }^{54}$ As reuniões foram proibidas e estabeleceu-se a censura nas comunicações telegráficas. ${ }^{55}$ Muitos grevistas foram presos e os advogados dos operários foram impedidos de embarcar para Jundiaí pelo chefe da polícia de São Paulo e tiveram seus pedidos de habeas-corpus negados pelos tribunais. ${ }^{56}$

Paralelamente, as organizações operárias encetavam uma ampla campanha em prol dos trabalhadores da Paulista. As manifestações de apoio ultrapassaram mesmo as fronteiras do Estado de São Paulo. Durante as duas semanas que durou a greve houve no Rio de Janeiro diversas reuniões pú- 
blicas, bem como tentativas, que não se concretizaram, de uma paralisação total nessa cidade:

\begin{abstract}
"Os delegados das associações operárias do Rio de Janeiro (...) depois de discutidos amplamente os justos motivos que levaram os operários da Companhia Paulista a se declararem em greve e as medidas por parte dos govemos estaduais e federais que estão sendo tomadas, e considerando que a remessa de forças para São Paulo é uma ameaça moral e física do proletariado em todo o Brasil, considerando que a intervenção do govemo estadual no conflito entre o capital e o trabalho é uma provocação ao brio do proletariado e um ataque à liberdade individual (...) resolveu: 1) aconselhar as associaçōes a realizar nas suas sedes sessões de protesto contra as medidas vexatórias dos governos de São Paulo e Federal; 2) aconselha ainda as administraçōes das associações que incitem constantemente ao operariado, por meio da palavra escrita e falada, a declarar-se em greve geral de protesto e solidariedade; 3 ) que as mesmas associações preparem e declarem, no momento preciso, se os governos se obstinarem na prática a afrontar o brio do proletariado e de violência contra os companheiros de São Paulo, a greve geral em todo o Rio de Janeiro". 57
\end{abstract}

No dia 19/05/1906, os ferroviários da Estrada de Ferro Funilense, do Ramal das Cobras, do Ramal Ferreo Campineiro e da Companhia Mogiana, com sede em Campinas, aderiram à decisão da Liga Operária daquela cidade e declararam-se em greve de solidariedade. Idêntica atitude tomaram os operários da construção civil, das principais fábricas, da limpeza pública; os tipógrafos $;{ }^{58}$ os alfaiates e os comerciantes. ${ }^{59}$ Por sua vez, a Federação Operária de São Paulo distribuiu grande quantidade de panfletos na Estrada de Ferro São Paulo Railway, através da qual eram embarcadas as forças policiais para Jundiaí, com o fito de conseguir sua a desão ao movimento grevista:

\footnotetext{
“Companheiros! A vossa atitude é triste! Não somente recusais a vossa solidariedade aos vossos irmãos em greve, mas colaborais na obra infame de violências, de coação, que a polícia, aliada dos patrões está executando contra os grevistas! Vós cooperais com as Companhias e com as autoridades parciais no esmagamento dum justíssimo protesto de trabalhadores vilipendiados! Sois vós que transportais os soldados, armados em guerra, que vão fazer aparato de força e exercer prepotências contra homens que, como vós, são vítimas de companhias mais cuidadosas dos dividendos do que do bem-estar dos operários! Não podeis amanhã precisar da solidariedade que hoje negais aos vossos companheiros?"60
} 
Pedidos semelhantes foram enviados aos trabalhadores das demais estradas de ferro, bem como aos operários das Docas. Frente à possibilidade da greve alastrar-se por outras empresas vitais à atividade agro-exportadora, Jorge Tibiriça, Presidente do Estado, telegrafou no dia 20/5 ao Presidente da República, pedindo a intervenção da força federal para "acalmar o movimento grevista". Também Antônio Prado procurou apoio de Rodrigues Alves, alegando a "parcialidade do governo estadual, a inércia das autoridades policiais e a ausência de qualquer apoio oficial". ${ }^{61}$ Em resposta foram enviados para Santos dois cruzadores e colocados de sobreaviso o 7 ? e o 22 ? batalhões de infantaria.

Nas diversas cidades servidas pela Companhia, a simpatia da população pelos grevistas foi manifesta. Sobretudo os comerciantes de Rio Claro, Jundiaí e Campinas não dissimularam suas tendências, como pode ser constatado no seguinte telegrama enviado às autoridades e que contava com mais de 200 assinaturas:

"Os comerciantes infra-assinados protestam à Liga franco apoio e os seus sentimentos de solidariedade, oferecendo a sua leal simpatia com o intuito de que a greve seja coroada de completo triunfo para a reivindicação dos direitos dos operários". ${ }^{62}$

Ao longo da greve, por várias vezes, o comércio cerrou suas por tas em sinal de apoio aos grevistas, respondendo prontamente ao pedido das Ligas para que não fosse fornecido às pessoas estranhas à região "nem pão, nem bebida, nem cama". ${ }^{63}$ A força policial aquartela da ao longo da estra da tinha que ser alimentada através da remessa de víveres vinda de São Paulo. Tal atitude contrastava claramente com a posição assumida pela diretoria da Associação Comercial:

"...a greve que paralisou de chofre o movimento das linhas da Companhia Paulista é medida extrema que não encontra simpatia pela fraqueza de seus fundamentos. A Associação Comercial de São Pau1o não pode calar seus sentimentos de estupefação ante um movimento que considera não uma reação violenta pela revolta natural dos espíritos contra um atentado do poder, mas a primeira refrega de uma agitação estremamente perigosa". ${ }^{64}$

Ao final da primeira semana, a situação não evoluira em nada: os trabalhadores, apesar de todas as pressões sofridas, mostravam-se inquebrantáveis, exigindo, senão a demissão, pelo menos o afastamento do engenheiro Monlevade do cargo de chefe da locomoção. O presidente da Paulista insistia em prestigiar acintosamente o seu funcionário e numa atitude de provo- 
cação, Antônio Prado fazia questão de realizar as reuniões na casa do Monlevade. A carta de alguns fazendeiros e comerciantes, estabelecidos à beira das linhas da estrada, bem exemplifica a oposição que tal política despertou nos setores mais diretamente atingidos pelo impasse:

\begin{abstract}
"Pode um homem valer mais do que 3800, nós não temos nada com isso. Mas achamos que os interesses da agricultura, do comércio e da indústria, devem valer mais do que certos caprichos. Ninguém indenizará ao comércio dos prejuízos que teve com essa crise, e aqueles que tem os seus capitais empregados nas empresas industriais tal fizeram por terem confiança no espírito sensato e na prudência daqueles a quem entregam o seu dinheiro". ${ }^{65}$
\end{abstract}

Mais do que mero capricho, essa maneira de conduzir a questão tipifica o alto grau de autoritarismo que permeava as relações de trabalho. Sem dúvida, toda questão poderia ser resolvida com a mera transferência do Monlevade. Entretanto, Antônio toma o problema como um desacato a sua autoridade e não consegue admitir que simples operários possam opnar na escolha dos empregados superiores da "sua" empresa. Como que para reafirmar a posição de comando que desfrutava, promoveu, ain da no decorrer da paralisação, o engenheiro Monlevade ao cargo de Inspetor Geral da Companhia. Em seguida, já cônscio de que poderia contar com ilimitada ajuda federal, decidiu não mais ensaiar qualquer negociação com os grevistas:

"Nas circunstâncias atuais e em vista dos atentados que estão sendo
praticados contra a propriedade da Companhia, com o fim de impe-
dir o tráfego da estrada, pondo em sério risco a segurança pública e
a vida dos auxiliares da Companhia, considero inútil qualquer nova
tentativa de acordo com os responsáveis por esses atentados. Peço
transmitir aos meus colegas de diretoria esta minha opinãa, que su-
jeito ao seu juízo que regulará meu proceder. A greve não está infe-
lizmente termina da mas posso assegurar que, continuando o governo
a prestar à Companhia o eficaz apoio da força pública como está fa-
zendo, o tráfego estará completamente restabelecido dentro de
alguns dias..." 66

O advogado da Paulista, Dr. Villaboim, passa a fazer largo uso da imprensa a fim de caracterizar o movimento como sedicioso. ${ }^{67}$

Concomitantemente, a diretoria da empresa deu ordem para que os trabalhadores em greve, residentes em casas da Companhia, desocupassemnas em vinte e quatro horas, sob pena de despejo judicial. ${ }^{68}$ A repressão recrudeceu. Na madrugada do dia 24/05, em Rio Claro, a polícia tomou de assalto o depósito onde a Liga armazenava os mantimentos e donativos ofe- 
recidos pela população. ${ }^{69} \mathrm{Em}$ Jundiaí foram apreendidos boletins que seriam distribuídos aos grevistas e os tipógrafos foram proibidos de executar qualquer trabalho para as ligas. As informações na grande imprensa eram desencontradas: o Correio Paulistano, jornal que outrora pertencera à família Prado, desde o início do movimento cerrou fileiras ao lado da Paulista, ${ }^{70}$ dando ênfase às palavras de Antônio Prado, que garantia ser eminente o resta belecimento do tráfego. Segundo o jornal, os trabalhadores encontravamse divididos e vários estavam desejosos de voltar aos seus postos, temendo apenas a atitude dos colegas mais exaltados. ${ }^{71}$ Essas informações eram amplamente desmentidas pelo Comércio de São Paulo, matutino que dedicava grandes espaços à greve e publicava a maioria dos boletins e manifestos das entidades operárias. ${ }^{72}$ Talvez a identificação desse último periódico com os grevistas explique-se, pelo menos em parte, pela presença de Benjamin Mota, jornalista, advoga do e militante libertário nạ redação do jornal. Já no final da greve, o mesmo foi demitido do cargo sob acusação de que suas notícias continham "comentário desvairados (...) moldura anarquista e fanfarrona que as estavam tornando até grotescas". ${ }^{73}$

No dia $26 / 05$, quando o movimento nas cidades servidas pela Companhia já dava sinais de arrefecimento, sob a coordenação da Federação Operária, a on da grevista atingiu a capital, que presenciou sua primeira greve geral. Gráficos, sapateiros, chapeleiros, mecânicos, operários têxteis, entre outros, solidarizaram-se com os ferroviários da Paulista, fazendo com que os principais bairros fabris tivessem suas atividades estancadas. ${ }^{74}$ As passeatas e reunióes foram violentamente dispersadas, tendo sido registrados inúmeros choques entre populares, grevistas e policiais. Nem o Largo São Francisco, considerado território neutro, foi respeitado. ${ }^{75}$ Os estudantes de direito, que engrossavam as fileiras dos grevistas, rebelaram-se contra o desrespeito aos direitos e liberdades garantidas pela Constituição, promovendo comícios públicos. ${ }^{7}$ Logo após uma entrevista entre o Presidente do Esta do e o diretor da faculdade, esta foi fechada por tempo indeterminado. ${ }^{77}$ As redações dos jornais Avanti e La Bataglia foram invadidas e as edições apreendidas, a sede da Federação Operária foi fechada. ${ }^{78}$

$\mathrm{O}$ alastramento da greve, primeiro nos locais servidos pela Companhia e depois na capital do Estado, atesta que as tensões sociais não se encontravam restritas aos ferroviários. Entretanto, a ampla mobilização de diversos setores sociais não foi suficiente para que se superasse a visão personalizada do conflito, o que se ocorresse teria dado margem ao afloramento de reivindicações mais radicais. Toda questão parecia resumir-se numa luta entre os "oprimidos e os malfeitores", que despertou de imediato a simpatia das camadas médias: 
“...o comércio de Rio Claro já se manifestou com relação à luta inesperada travada entre a Companhia Paulista, depositária de enormes capitais e seus operários, que se conservam em atitude resignada e pacífica até a satisfação de seus pedidos". 79

Não só as atitudes de Antônio Prado, mas o que representava sua própria figura, destacadíssima no interior da elite dominante nacional, acabaram por reforçar tal compreensão do movimento.

Em Jundiaí, bem como nas demais cidades, tornava-se impossível resistir às pressões da Companhia e da polícia. No dia 29 , quando o movimento já estava em declínio, ${ }^{80}$ ocorreu um violento conflito na cidade de Jundiaí entre alguns grevistas e as forças policiais, que resultou na morte de dois operários e um soldado. ${ }^{81}$ As informações sobre o ocorrido são contra ditórias. A polícia afirmou que os trabalhadores tentaram assaltar as oficinas da Paulista, no que foi contestada pelas entidades operárias, que acusavam as forças policiais de tentar dissolver através da força uma reunião de grevistas. $^{82}$

Em face da conjuntura, a Federaçãao Operária de São Paulo distribuiu boletins, recomendando a volta ao trabalho. No último dia de maio, o tráfego estava totalmente restabelecido, sem que os operários alcançassem nenhuma de suas reivin dicações.

\section{IV) CONSIDERAÇÕES FINAIS}

A greve da Companhia Paulista ocupa lugar de destaque no conjunto das manifestações operárias dos inícios da República, merecendo ser particularizada. Em primeiro lugar, deve-se ressaltar que ela ocorreu num momento em que politicamente a classe operária encontrava-se mobilizada e no qual o anarquismo firmava-se como corrente ideológica predominante. Foi o grau de organização e mobilização que distanciou essa greve de grande parte dos acontecimentos similares que povoaram o período, alguns deles próximos do espontaneísmo. O movimento de 1906 coloca em questão a propalada falta de capacidade organizativa dos literários, justificativa normalmente utilizada para explicar seus "insucessos". A atuação das entidades proletárias, tanto na deflagração como no decorrer da greve, torna patente que as mesmas foram capazes de interpretar e dirigir o descontentamento reinante não apenas entre os operários da Paulista, mas em grande parte da classe trabalhadora, ainda que lhes escapasse uma compreensão mais crítica das reais causas do movimento.

A tecnificação introduzida pela Companhia e as tentativas de dificultar a organização autônoma dos trabalhadores foram apreendidas de maneira 
personalizada, sem que se tocasse no âmago da questão. Certamente não se poderia "culpar" a liderança anarquista pela estreiteza dos objetivos em jogo. Em realidade, as atitudes tanto do operariado quanto do patronato mostram que as relações entre o capital e o trabalho ainda se recentiam da herança da sociedade patriarcal e agrária; as partes em luta entraram em cena, fazendo uso de discursos arcaicos que não se coadunavam com o papel que doravante deveriam representar. Os operários, na sua grande maioria imigrantes, ainda traziam consigo uma bagagem de valores e crenças herdadas da produção artesanal. As reivindicaçōes tornam patente que a exploração capitalista não havia sido apreendida enquanto tal. Fundamentalmente reclamava-se da não observância da hierarquia de funções que compunham a "carreira operária de ferroviário" e pedia-se o direito do trabalha dor ser tratado pelos superiores com a dignidade que indivíduos honestos e honrados mereciam. A introdução de tecnologia poupadora de mão-de-obra e a exigência de maior produtividade foram associados à figura do engenheiro Monlevade, que consubstanciava a nova política da empresa. $\mathrm{O}$ afastamento desse "inimigo dos operários" seria suficiente para resolver todos os problemas.

Já o patronato, acostumado a exercer as prerrogativas do senhor de escravos, não podia admitir que meros operários pudessem vir a opnar sobre o quer que fosse. Antồnio Prado considerou as reivin dicações como uma tentativa de subversão da ordem natural das coisas, só podendo ser enfrentada com exemplar repressão. A mera transferência do engenheiro Monlevade, que em nada alteraria a política da Companhia, teria sido suficiente para que a greve terminasse. Entretanto, jamais se cogita em aceitar os operários como interlocutores válidos. $\mathrm{O}$ conselheiro obstinadamente insiste em manter o engenheiro Monlevade e até o promove, numa clara afirmação de sua autoridade. Essas atitudes, alia das à massiça intervenção da polícia, acabam por fazer com que as camadas médias, comovidas, aliem-se aos grevistas. Os fazendeiros, que sofriam grandes prejuízos com a greve, mostravam-se inconformados com a atitude de Antônio, tachando-a de caprichosa. $\mathrm{O}$ desenrolar dos fatos mostra que a exploração capitalista foi percebida, por ambos os lados, como uma questão de honra, onde nehuma das partes queria ser a primeira a transigir.

Entretanto, 1906 não ficaria no limbo. Em 1917 a classe operária voltaria a repetir uma paralisação generalizada semelhante à de 1906. Certamente num outro contex to histórico e com outra voz. 


\section{NOTAS}

${ }^{1} \mathrm{~A}$ desistência dos ingleses é colocada por alguns autores como resultado das pressões exercidas pelos cafeicultores, interessados no empreendimento. Ver: CASTRO, Ana Célia - As Empresas Estrangeiras no Brasil, 1860/1913, RJ, Zahar Editores, 1979, p.43. Entretanto, a posição inglesa pode ser melhor entendida, levando-se em conta que através da Santos-Jundiaí eles obtiveram o controle do transporte de todo o café do Estado. Nenhuma outra linha poderia ser tão rentável quanto a que já possuíam. Ver: SAIS, Fávio Azevedo Marques de - As Ferrovias de São Paulo, 18701940 , SP, Hucitec/ INL, 1981, p.175/6.

${ }^{2}$ DARRElL, E. Levi - A Famtlia Prado. SP, Cultura 70 Editora S/A, 1977, p.253, afirma que os dividendos pagos entre $1872-1922$ não foram inferiores a $7 \%$ em todos os anos exceto um, com média anual de mais de $10 \%$.

${ }^{3}$ Para a evolução da produção cafeeira nos municípios cortados pela Paulista ver: CAMARGo, José Francisco de - Crescimento da População do Estado de São Paulo e Seus Aspectos Econômicos, SP, Instituto de Pesquisas Econômicas, 1981, volume I, pp. 33 e 40.

${ }^{4}$ Idem/ibidem, p. 217.

${ }^{5}$ CASTRO, Ana Célia, op. cit. p.43; SAES, Flávio Azevedo Marques de, op. cit. p.166.

${ }^{6}$ CANO, Wilson - Raízes da Concentração Industrial em São Paulo, SP/RJ, 1977, pp.52 e 53.

${ }^{7} \mathrm{DEAN}$, Warren - A Industrialização de São Paulo, SP/RJ, Difel, s/d, 3a ed., p.44.

${ }^{8}$ CANO, Wilson, op. cit. p.53.

${ }^{9}$ MATtOON JUNIOR, Robert H. - The Companhia Paulista de Estradas de Ferro, 1868-1900: A Local Railway Enterprise in SP, Brazil, 1971. Tese apresentada à escola de pós-gra duação da Universidade de Yale, postulando o grau de doutor em filosofia. Microfilmes da Universidade de Michigan, 1972, pp.45 e 47. APUD: CASTRO, Ana Célia - ob. cit. p.43.

10 Relatório da Companhia Paulista de Vias Férreas e Fluviais. São Paulo, Casa Vanorden, 1918 , p.8.

${ }^{11}$ Sobre a vinculação entre os Prado e a Companhia Paulista ver: DARREELL, E. Levi, ob. cit. p. 250 e ss.

${ }^{12}$ CONRAD, Robert - Os Ôltimos Anos da Escravatura no Brasil (1850/1888), Editora Civilização Brasileira/INL, 1975.

${ }^{13}$ DARRELL, E. Levi - ob. cit. p.184.

${ }^{14}$ Idem/ibidem, p. 253 e SAES, Flávio Azevedo Marques de - ob. cit. p.167.

15FAÚSTO, Boris - Trabalho Urbano e Conflito Social, RJ/SP, Difel, 1977, p.140, coloca esse ponto em relevo.

${ }^{16}$ DULLES, J.W.F. - Anarquistas e Comunistas no Brasil, RJ, Nova Fronteira, 1977, p.28. 
${ }^{17}$ As discussões e teses aprovadas no 1 ? Congresso Operário Brasileiro podem ser encontra das em RODRIGUES, Edgard - Alvorada Operária, RJ, Ed. Mundo Livre, 1979, pp.96 a 114.

${ }^{18}$ DIAS, Everar do - História das Lutas Sociais no Brasil, SP, Alfa-Ômega, 1977, p. 251. 19 Idem/ibidem, p. 255.

${ }^{20}$ RODRIGUES, Edgard - ob. cit. p.101.

${ }^{21}$ A notícia da fundação das Ligas é da da por DIAS, E. - ob. cit. pp. 250 e 253 . FAUSTO, B. - ob. cit. p.140, nota 11. Afirma, baseado em dados do jornal A Terna Livre de $24 / 03$ e 12/04/1906, que a fundação da Liga de Jundiaí contou com a participação de Edgard Leuenroth.

22 O Comércio de São Paulo, 15/05/1906.

23 DIAS, E. - ob. cit. pp. $256 / 257$.

${ }^{24}$ O Comércio de São Paulo, 16/05/1906.

25 Idem/ibidem.

${ }^{26} \mathrm{Idem} /$ ibidem, entrevista de Antônio Prado.

27،....de há muito tempo se previa esse movimento grevista, constando-nos até que no dia 12 do corrente, em zona da linha, além de Rio Claro, a greve fora inicia da, sem resultado, porém, pois que o comitê da Liga Operária nada resolvera ainda definitivamente em relação à greve geral" Cidade de Campinas, 16/05/1906. Notícias semelhantes em O Comércio de São Paulo, 19 e 23/05/1906.

${ }^{28}$ O Comércio de São Paulo, 15/05/1906.

${ }^{29}$ KOWARICK, Lúcio - Escravos, Párias e Proletários, Tese de Livre-Docência apresentada a FFLCH da USP, 1981, ed. mimeog., p.283 e ss.

${ }^{30}$ Entrevista de Antônio Prado ao O Comércio de São Paulo, 16/05/1906.

${ }^{31}$ Entrevista de Torres Neves, inspetor geral, ao Correio Paulistano, 16/05/1906.

32 Entrevista de Antônio Prado ao O Comércio de São Paulo, 16/05/1906.

${ }^{33}$ Esses pontos são ressalta dos por FAUSTO, B. - ob. cit. p.142.

${ }^{34}$ O Comércio de São Paulo, 19/05/1906, carta da Liga ao inspetor.

35 Idem/ibidem. Ainda no mesmo documento encontram-se considerações análogas em relação aos trabalhadores da conserva.

${ }^{36}$ Idem/ibidem.

${ }^{37}$ Idem/ibidem.

${ }^{38}$ Fanfulla, 17/05/1906. APUD: FAUSTO, B. - ob. cit. p.143. E no mesmo sentido: " $O$ chefe da Estação Jundiaŕ vive abusando do seu cargo, vive a ameaçar, a injuriar (...). Estes fatos (...) que vem ofender a nossa dignidade de honestos operários que não se julgam escravos, nem querem submeter-se às arbitrariedades dos superiores déspotas, não podem nem devem continuar". Boletim da Liga Operária de Jundiaí, publicado no O Comércio de São Paulo, 15/05/1906.

${ }^{39}$ Segundo afirmaçōes do advogado da companhia, esta contribuía anualmente com 50 contos de réis. Correio Paulistano, 27/05/1906. Os estatutos determinavam que esse dinheiro fosse aplicado em ações da própria companhia Diário Oficial do Esta do de São Paulo, 03/05/1906. 
${ }^{40}$ SIMÃO, A - Sindicato e Estado, SP, Dominus, 1966, p. 203 e ss. fez um levantamento dessas associações.

41 O Comércio de São Paulo, 23/05/1906. Queixas semelhantes eram comuns no período: "Esta companhia [Sorocabana] que mantinha uma associação com farmácia começa a fazer disso um meio de vida, cobrando aos associados preços exorbitantes pelos remédios, quando eles contribuem com mensalidades de 3 e $6 \$ 000 "$. A Capital, 22/02/1915. APUD: KOWARICK, Lúcio, ob, cit. p.326.

${ }^{42}$ Diário Oficial do Estado de São Paulo, 03/06/1906.

${ }^{43}$ RODRIGUES, E. - ob. cit. pp.107 e 108 - Resoluções do 1 \% Congresso Operário Brasileiro.

${ }^{44}$ Ver, por exemplo, A Tribuna de Santos, 9, 10, 14 e 16/04/1906.

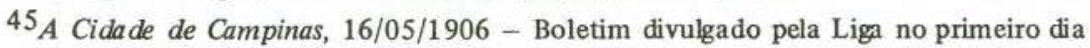
de paralisação.

${ }^{46}$ Correio Paulistano, 16/05/1096.

${ }^{47}$ O Comércio de São Paulo, 17/05/1906. A assembléia geral da sociedade foi convocada para o dia 20/05. Provavelmente a reunião não chegou a realizar-se pois, segundo atas da sociedade, publicadas no Diário Oficial do Estado de São Paulo em 07/04/1907 e em 06/08/1909, o referido artigo continuava em vigor, figurando em ambas o engenheiro Monlevade como presidente da sociedade.

${ }^{48}$ Correio Paulistano, 17/05/1906.

49."...a escravidão foi durante vários séculos o paradigma norteador das relações de trabalho, com todas as funestas conseqüências no que diz respeito à solidificação de um arbítrio que encarava a mão-de-obra como coisa que poderia e deveria ser usada e abusada sem limites. Tudo leva a crer que, uma vez term inado o cativeiro, muito desta postura senhorial continuou a contaminar as relaçōes de exploração do trabalho" KOWARICK, Lúcio - (ob. cit. p.271).

50 Este ponto é colocado em destaque por FAUSTO, B. - ob. cit. p.141.

51 o Comércio de São Paulo, 16/05/1906.

520 Comércio de São Paulo, 17, 18 e 19/05/1906 noticia a chegada dos elementos que deveriam substituir os grevistas. Segundo A Cidade de Campinas, 17/05/1906. Antônio Prado telegrafou para o Rio de Janeiro, pedindo 800 operários, que se negaram a vir por serem solidários aos grevistas. A mesma resposta foi obtida na Companhia Leopoldina e na Central do Brasil.

53 Correio Paulistano, 18/05/1906.

54 O Comércio de São Paulo, 25/05/1906.

55 O Comércio de São Paulo, 20/05/1906, noticia a alteração do conteúdo de telegramas e a proibição de envio dos mesmos.

${ }^{56} \mathrm{Os}$ advogados foram proibidos de embarcar para Jundiaí. Quando conseguem chegar à cidade, através de um pedido de habeas-corpus, são mandados de vol ta. Nova habeascorpus thes foi negado.

${ }^{57}$ O Comércio de São Paulo, 23/05/1906. Em Santos foi distribuído o seguinte boletim: "Ao operariado em gerall Preparem-se para a luta. O momento é oportuno. Estejam de prontidão ao primeiro grito de greve. Vamos aderir aos nossos companheiros da Paulista" - Correio Paulistano, 20/05/1906. 
${ }^{58} \mathrm{~A}$ greve dos tipógrafos impediu que o jornal Cidade de Campinas fosse publicado entre 19 e 25/05/1906. Depois desse episódio, o jornal colocou-se favoravelmente à companhia.

${ }^{59}$ Notícias sobre a paralisação em Campinas podem ser obtidas no: Correio Paulistano, 20/05/1906.

${ }^{60}$ O Comércio de São Paulo, 24/05/1906.

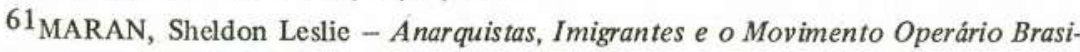
leiro (1890/1920), RJ, Paz e Terra. 1979, p.34.

62 o Comércio de São Paulo, 16/05/1906.

${ }^{63}$ A íntegra do pedido da Liga é a seguinte: "Pedimos ao comércio de Jundiaí, solidário conosco, que feche as suas portas em sinal de protesto contra os nossos opressores, e não forneça às pessoas estranhas em Jundiaí nem pão, nem bebida, nem cama". $O$ Comércio de São Paulo, 18/05/1906.

${ }^{64}$ Idem/ibidem. FAUSTO, Boris - ob. cit. pp.145/146 enfatiza as diferentes posiçōes assumidas, de um lado, pelos comerciantes das cidades atingidas pela greve, e, de outro, pela diretoria da Associação Comercial.

650 Comércio de São Paulo, 21/05/1906. E no mesmo sentido afirmavam os comerciantes de Rio Claro: "Em solidariedade com os operários da Companhia Paulista, pela justiça que lhes assiste em suas reclamaçōes (...) à vista da atitude caprichosa da mesma Companhia, tão-somente em prol de três empregados subalternos, protesta contra esse insólito procedimento e pelos danos que aos seus interesses ora estão sendo acarretados. Portanto, pedimos ao governo do Estado urgentes providências" $O$ Comércio de São Paulo, 17/05/1906.

${ }^{66}$ Carta enviada por Antônio Prado à diretoria da Companhia, da qual recebeu amplo apoio. Correio Paulistano, 23/05/1906.

${ }^{67}$ As posições do advogado estão expressas no Correio Paulistano, 27/05/1906. O jornal $O$ Comércio de São Paulo publicou, na mesma data, um artigo de Benjamin Mota, que então ocupava o cargo de redator, combatendo violentamente as posturas do Dr. Villaboim.

${ }^{68}$ o Comércio de São Paulo, 22/05/1906.

${ }^{69}$ Em mais de uma oportunidade, a população em geral mostrou-se simpática ao movimento grevista, inclusive vaiando as forças policiais que eram embarcadas para Jundiaí. Vários abaixo-assinados e subscrições foram feitas em favor dos trabalhadores. $O \mathrm{Co}$ mércio de Sāo Paulo, 19 e 20/05/1906.

70 "Não raro, os operários oprimidos por um regime desumano a que são condenados pelos patrões, congregam-se em torno de um nobre ideal, buscando libertar-se do jugo que os torna quase escravos e então exercem dignamente o direito de greve. Infelizmente, porém, o movimento paredista, que se declarou (...) na importante Estrada de Ferro Paulista destoa por visar exclusivamente o desprestígio de superiores hierárquicos, cuja conduta tem sido sempre irrepreensível sob todos os pontos de vista" O Correio Paulistano, 17/05/1906.

${ }^{71}$ Correio Paulistano, 24/05/1906.

${ }^{72}$ A postura do jornal é clara: "As ciladas são muitas e a luta não é leal da parte da Companhia que, não contente em ter a força das baionetas para cometer toda sorte de 
violências físicas e a aliança ciente ou inconsciente de certa imprensa, quer, com notícias combinadas com a polícia, desnortear a opinião pública, fazendo-lhe acreditar que a greve está quase terminada e o tráfego quase restabelecido (...). Não ignoramos que o senhor Dr. Antônio Prado tem lançado mão de todos os recursos para esmagar esse movimento operário, teimando em não atender as queixas que tem esse operariado contra o Sr. Dr. Monlevade que ele quer sustentar, como declarou aos próprios grevistas, à força...". O Comércio de Säo Paulo, 26/05/1906.

${ }^{73}$ Ver: $O$ Comércio de São Paulo, 01/06/1906, onde justifica-se a demissão do redator. Em relação à atuação domesmo no movimento operário ver: DIAS, Everardo, ob. cit. p.250.

${ }^{74}$ Os jornais publicam, a partir de $27 / 05 / 1906$, abundantes dados sobre as paralisações na capital.

75 Correio Paulistano, 29/05/1906.

${ }^{76}$ Ficou célebre a passagem em que, diante das violências da polícia, um estudante inquiriu o delegado a respeito dos direitos constitucionais. A resposta não deixa margem à dúvidas: "AHI a Constituição... isso lá eles a interpretam como entendem!", $O$ Comércio de São Paulo, 28/05/1906.

${ }^{77}$ O Comércio de São Paulo, 31/05/1906.

${ }^{78}$ DIAS, Everardo - ob. cit. p. 258.

${ }^{79} \mathrm{O}$ Comércio de São Paulo, 23/05/1906. Ê dentro desse contex to de polarização entre o "bem" e o "mal" que se pode compreender o apoio e a solidariedade que o movimento grevista despertou.

${ }^{80}$ Os ferroviários da Mogiana voltaram ao trabalho no dia 26 , sob ameaça do governo de encampamento da ferrovia. O Comércio de São Paulo, 26/05/1906.

${ }^{81}$ Antônio Prado, numa atitude que desgostou os empregados da Paulista, encarregouse do enterro e deu uma pensão à família do soldado morto, sem fazer o mesmo em relação aos trabalhadores. Ver: CARONE, E. - Movimento Operário no Brasil (1877. 1944), RJ, DIFEL, 1979, p.94. APUD: “A Terra Livre", 13/06/1906 e DIAS, Everardo - op. cit. p. 258.

${ }^{82}$ O Comércio de São Paulo, 26/05/1906.

"Universidade de São Paulo

Pós-graduação em História

Caixa Postal 8105

05.508 São Paulo - SP 